\title{
The Impacts of Novel Coronavirus (COVID-19) Pandemic Outbreak on Global Economy: A Quantitative Analysis
}

Md. Amir Hossain*

PhD (Research Scholar) in English literature, Jahangirnagar University, Bangladesh

DOI: $10.36347 / \mathrm{sjebm} .2020 . \mathrm{v} 07 \mathrm{i} 06.001$

| Received: 02.06.2020 | Accepted: 15.06.2020 | Published: 16.06.2020

*Corresponding author: Md. Amir Hossain

Abstract

Review Article

The aim of this paper is to investigate the recessive impacts of the novel coronavirus (COVID-19) pandemic outbreak on the global economy in reference to the reports of the international agencies, including UNCTAD, OECD, UN, DESA, IBIS, and CDCP. How millions of people living in the vulnerable countries of the world are being infected and affected by the fatal virus is the main target of this study. The dreadful effects are prevailing in the global economy. Consequently, the worst case scenario has been created in macro economies. Global economy has become paralyzed and become stagnant. For this purpose, the paper would like to focus on the duty and responsibility of the global leaders through coordination and cooperation so that global economy can be invigorated. The impacts of the coronavirus on unemployment, capital flight, contraction of foreign direct investment, supply shock, demand shock, manufacturing industries, electronic goods, hospitality, tourism and cruise ships, oil prices, pharmaceuticals and healthcare, fashionable and luxurious products of the whole world have been discussed in this paper faithfully. Also, the adverse impacts of the COVID-19 on Bangladesh economies, including garment industries, remittance, and internal economy have been unveiled. Thus, paper would like to explore the current picture of the global economic crisis.

Keywords: Novel Coronavirus (COVID-19), UNCTAD, OECD, UN, DESA, and Global Economy.

Copyright @ 2020: This is an open-access article distributed under the terms of the Creative Commons Attribution license which permits unrestricted use, distribution, and reproduction in any medium for non-commercial use (NonCommercial, or CC-BY-NC) provided the original author and source are credited.

\section{INTRODUCTION}

According to Mohamed A. El-Erian, Chief Economic Adviser, Allianz, "For many developing countries, the crisis may barely have begun, and the human toll of a major COVID-19 outbreak would be orders of magnitude lager than in any advanced economy." Many vulnerable nations all over the world are now facing multiple crises owning the major COVID-19 outbreak which is hard to predict. Macro economies are falling into a great recession.

The World Economic Outlook highlights the global growth in the year 2020 to slow down to $3 \%$. There is a substantial uncertainty about the effects on the lives and livelihood of the vulnerable communities of the world. The coronavirus pandemic spread, the effectiveness of containment steps, and the development of therapeutics and vaccines, all of which are difficult to express in words or language. Moreover, millions of people are now facing multiple crises, for example, health crisis, financial crisis, and collapse in commodity prices, which interact in difficult issues. The global policymakers are being found to provide the unprecedented support to households, industries, and financial markets. But, the fact is very dreadful to recover. There is a substantial uncertainty about the impacts of the novel coronavirus on the global economy as well as massive humanity emerging from the great lockdown [1].

The great lockdown is an ongoing severe global economic recession [2]. The economic effects of the COVID-19 pandemic outbreak has become more visible in the world economy on 20 February 2020 with the stock market crash [3]. The recession has been the steepest economic downturn since the great depression. Elliott, 14 April 2020 [4], On 14 April 2020, the International Monetary Fund has reported that the G-7 nations have already entered into a deep recession, along the western countries with the significant slowdown of growth across developing and emerging economies [5]. The pandemic has led to more than a third of the global population being placed on the lockdown to stop the outbreak of the novel coronavirus [6]. It has caused crucial repercussions for economies all over the globe [7]. 
Now, this study would like to examine the impacts of the novel coronavirus (COVID-19) pandemic on the global economy and massive humanity in the light of information as well as reports expressed by the UNCTAD, OECD, UN, DESA, IBIS, and CDCP. Based on the reports, the study has been conducted to show the practical image of the world's economic crisis of the vulnerable nations. The great lockdown, quarantine and home quarantine have paralyzed the lives and livelihood of millions of people. People are compelled to stay at home; their income source has been stopped; Food crisis, shortage of medicine and cloth, health crisis, unemployment, mental disorders, and financial crisis-all of which have become very pitiable and acute. Industries and firms, garments exports and imports, restrictions on travel, electronic goods, hospitality, tourism and cruise ships, oil prices, pharmaceuticals and healthcare, fashionable and luxurious products are the glaring instances of macro economies. All these are the victim of the coronavirus pandemic outspread.

Economists think that the clutches of the fatal coronavirus on the national economy of Bangladesh is no less than any other country of the world. Garments industry has been playing an important role in earning finance.

In Bangladesh, about 35 lakhs of workers in 4,825 garment factories produce goods for export to the global market, especially Europe and America. Bangladesh Garment Industry generates $80 \%$ of the country's total export revenue. The textile and clothing industries provide the single source of growth in Bangladesh's rapidly developing economy. Exports of textiles and garments are the principal source of foreign exchange earnings. The majority of garment workers earn little more than the minimum wage, calculated at 5,000 taka a month, far below what is considered a living wage, calculated at 8,000 taka a month, which will be the minimum required to maintain a very small family with shelter, food and education. For this purpose, what sorts of crisis Bangladesh economy may face during the coronavirus pandemic has been discussed in this study.

\section{UN DESA}

The whole world is now facing a turbulently economic crisis. Each and every country falls a victim of financial constraints. Millions of people are now suffering from hunger, starvation, and food crisis. Most of them have lost their jobs and have become unemployed. They have no other alternative means to maintain their livelihood. They are awaiting eagerly when better days will come again; and when they will go back to their respective jobs. Nobody knows when they will be able to fulfill their demands and mental desires. It needs no telling the fact that the world is now on the brink of economic crisis. Many poor people are begging from door to door due to the coronavirus pandemic outbreak.

According to the United Nations, the global economy may shrink by about $1 \%$ by the year 2020 due to the COVID-19 pandemic outbreak. The Department of Economic \& Social Affairs (DESA) also exposes the fact that the COVID-19 pandemic outbreak is disrupting supply chain and business activities around the world. Most of the vulnerable countries of the globe have closed their national borders during the past months. As a result, the movement of the people and tourism flows come to a screeching halt and to stand still. The whole world is now facing a turbulently economic crisis. Their lives have become helpless and paralyzed. Their income source have been stopped especially among the lives of the under-developed countries of the world. Those who live from hand to mouth are begging from door to door. The corrupt government does not pay heed to their request [8].

According to the United Nations, global economy may shrink a reversal from the previous forecast of $2.5 \%$ of the economic growth, the UN warns that the contract may further if the restrictions on the global economic activities are enlarged without any fiscal responses. By comparison, it warns that the world economy contracts $1.7 \%$ during the financial crisis in 2009. Restrictions on economic activities are creating unemployment rate, which will certainly make millions of lives jobless, addicted and involved into anti-social activities. In the DESA's report it is said that fear and anxiety of the pandemic outbreak of the coronavirus and difficult saturations about the containment steps have created financial constraints in the vulnerable countries of the globe. With the market volatility surpassing its peak during the financial crisis, equity markets, and oil prices are creating economic backdrops. Millions of the workers around the world are losing their jobs; becoming unemployed; suffering from hunger. Their whole financial conditions have paralyzed. The governments are considering and rolling out that there are a large number of packages which avert a sharp downturn of their economies through plunging the recession of global economy. In the worst case scenario, the global economy contract by $0.9 \%$ within the year 2020 .

According to the economists, within the upcoming years, the vast majority of the global population will have to face a dire results of economic crisis. The DESA further points out that contraction may be higher if the governments fail to provide income supports and help consumer boost expenditure. Before the outbreak of the coronavirus (COVID-19), the global output was expected to enlarge $2.5 \%$ within 2020. By changing economic conditions, the UN DESA's World Economic Forecasting Model focuses on the better and worse scenario for the global development. In the better-case scenario, the moderate 
decline in the private consumption, investment, exports, and offsetting increases in the government spending in the G-7 countries and China global growth fails to $1.2 \%$ in 2020. On the other hand, in the worse-case scenario, the global economy may contract $0.9 \%$ in place of $2.5 \%$. This scenario is based on the demand side shocks of different magnitudes of China, Japan, South Korea, US, and EU as well as oil price decrease of $50 \%$ against the baseline of $\$ 61$ per barrel. The scenario of the global economy is undergoing a divergent change.

The severity of economic impacts depend on the two main factors: the duration of restrictions on the movements of people and economic activities in the main economies, and the real size of efficacy and the fiscal responses to the current crisis. The DESA's report highlights the fact that the negative effects of the current economic restrictions in the developed nations of the world will spill over into the developing countries. As a result, the lower trade and investment will begin to decline since trade and capital relies upon the economic prosperity and development. If the economic supply chain comes into a lower level, the economic situation of the majority of the people will be stagnant.

From the DESA's report, it is seen that if the restrictions on the global economic activities are on the increase day by day, the standard living condition of millions of people will be decreasing drastically. Business trade, capital, labor, and investment will be on the decline. At one stage, the whole economic situation will turn into a dreadful change.

The DESA's report also shows that several automobile companies have announced the large-scale production suspensions in Europe and the United States and many multinational firms especially in the auto, consumer electronics and telecommunications industries will have to face shortages of intermediate components as exports from China being contracted at an annual pace of $17.2 \%$ in the first two months of the year 2020 .

According to the DESA 2020, "A welldesigned fiscal stimulus package, prioritizing health spending to contain the outbreak of the virus and providing the income source aid to the households affected by the pandemic will help to minimize livelihood of a deep economic recession." From this quote, we can learn that if the economic income source lessens, the people have face hurdles and barriers to maintain the standard living condition. To hold normal health condition will be a difficult concern for the majority of the global population.

According to the forecast, lockdowns in Europe, North America and other countries of the world are hitting the service sectors, particularly the industrial sectors that involve physical interactions, such as retail trade, leisure and hospitality, recreation and transportation services. Industries account for more than a quarter of all kinds of jobs in the global economies. The UN warns that the pandemic outbreak of the novel coronavirus will bring a destructive change on the industrial sectors globally. Even to maintain the retail trade, the people may not have capability. In fact, recreational activities, hospitality, leisure and physical interaction will turn into dangerous situations.

The DESA's report expresses that as businesses lose revenue, unemployment rate may increase through transforming the supply side shock to the wider demand side for the current global economy. Against this backdrop, the DESA along with the UN system calls for the well-designed fiscal stimulus packages to prioritize health spending and support households, being affected by the virus pandemic spread. As a matter of fact, unemployment rate will be on the increase in the vulnerable countries slowly. The Secretary General for the Economic and Social Affairs Liu Zhenmin points out: "Urgent and bold policy measures are needed, not only to contain the pandemic and save mankind, but also to protect the greatly vulnerable countries from the ruin and to sustain economic development and financial stability." From this statement, it is realized that pragmatic measurements ought to be implemented as earliest feasible if we want to stabilize our economic supply chain or save the vulnerable communities from this chaotic situation. The DESA's report also warns that the adverse effects of the prolonged economic restrictions in the developed economies will spill over to the developed countries via trade and investment channels. A sharp decline in the consumer spending in the European Union and the United States will reduce the imports of consumer goods from the developing countries. For this situation, the export and import policy around the world will be reversal. In this regard, the DESA's report is very much pertinent. The Developing countries, depending on tourism and commodity exports, will face the severe economic crisis to a large extend. Many travelers may hurt tourism sector in the small island developing countries, where the low paid workers are employed. Meanwhile, the decline in the commodity related revenues and a reversal of the capital flows will be affecting the livelihood of the debt distress for many people of the world. The governments may be forced to curtail the public expenditures to protect the coronavirus pandemic spread and also consumption and investment can be supported.

Tourism sector will be greatly harmed due to the pandemic spread of the coronavirus. In this regard, we can mention the name of some countries, Singapore, Switzerland, Middle East, Europe, USA, UK, etc. Tourism business brings a radiant income source for the countries which are largely dependent on this sector. 
Unfortunately, this situation will be prolonged, tourism sector will be reversed.

UN-Chief Economist and Assistant Secretary General of the Economic Development Affairs Elliot Harris says that the collective goal must be a resilient recovery which puts the world back on a sustainable track. Harris also argues that the people must not lose sight how it is affecting the most vulnerable population. Economic development and implementation are indispensable to tackle the current situation. All the vulnerable countries must work together right now if they jointly prevent this terrific situation. If it is delayed to tackle this crisis, the governments will have to face dire results of the coronavirus pandemic outbreak. To stabilize economic development and implementation policy, the international agencies, including UN, ILO, WTO, WEF, WHO, IMF, and WB must come forward in this regard indeed.

The UN experts issue a broad appeal for the coordinated comprehensive multilateral response through amounting to $10 \%$ of the global gross domestic product. Experts also point out that the recent collapse in the global commodity prices is compounding the bleak fiscal outlook for the vulnerable countries, which have not recovered from the after-effects of the sharp commodity price declines in 2014-2016. The worsening pandemic is increasing deep-seated economic anxiety. Even in many high-income countries, a significant proportion of the population does not have enough financial wealth to live beyond the national poverty line for three months for which the economic security will be the prime concern.

From economic point of view, it can be stated here that millions of people in the global south and Africa live below the poverty line. If the prices of the essential commodities are hiking, people will have no capacity to purchase food products or other things to remove their hunger. At one stage, food crisis will reach the highest level in many parts of the world.

\section{UNCTAD}

The UN's Trade and Development agency reports that the slowdown in the global economy caused by the coronavirus outbreak is supposed to have cost at approximately $\$ 1$ trillion. The United Nations Conference on Trade and Development (UNCTAD) also reports that the fall in oil prices has been a contributing factor to the growing sense of unease and panic. This organization also expresses its report that apart from the tragic human consequences of coronavirus epidemic, economic uncertainty may cost global economy to $\$ 1$ trillion in the year 2020 [9]. Richard Kozul Wright, Director, Division on Globalization and Development Strategies at the UNCTAD, points out that people envisage a slowdown in the global economy to under $2 \%$ for this year 2020 , and it may cost $\$ 1$ trillion.
According to Duffin (3 April 2020), the global economy is likely to decrease about $2.4 \%$ of the value through the Gross Domestic Product (GDP) in 2020. The global economic growth rate may slow down from $3.0 \%$ to $2.4 \%$. The global GDP is likely to be estimated at about 86.6 trillion US dollars in 2019, which means that a $0.4 \%$ of drop in the economic growth amounts to approximately 3.5 trillion US dollars in the lost economic output. Such predictions were made prior to the COVID-19 global pandemic with a view to implementing the widespread restrictions on social contact to control the spread of the virus. Since then, global stock markets have suffered dramatic falls due to this crisis. As a result, a huge amount of loss will fall on global economy. It becomes apparent that if the global economic balance will be reversed, automatically, the economic growth rate will be reduced. Especially the global business and trade market policy will be a devastating turn due to the coronavirus pandemic spread.

\section{UNIDO}

UNIDO's data (2019) [10] highlights a decline in the production growth through indicating an economic slowdown just before the spread of the coronavirus crisis. Manufacturing output growth falls below the landmark of $1 \%$ and remains at around $0.7 \%$. In December 2019, the three industries register a positive year-over-year growth rate in the basic pharmaceutical products, beverages, and food products. While these industries represent the essential basic consumer goods, other manufacturing industries are likely to suffer a blow and resulting in economic implications owning to coronavirus crisis. As a result, the world GDP growth is likely to decline in the year 2020.

According to UNCTAD, the channels of global economy may get disrupted, like demand, supply, and finance. On the demand level, due to the mixture of reduced income source and fear of contagion, expenses' capability of the vulnerable communities will slow down. Despite being offset by the government spending, coronavirus shock's net demand policy may impact negatively in the short run.

Amplified by the negative supply side effect, it attributes to a drastic ban in manufacturing activities in the vulnerable regions and the resulting bottlenecks in the global value chain. Such disruptions will impact upon the widespread factory closures owning to the lack of intermediary inputs, even in the regions less infected by coronavirus. The increased risk aversion, the flightto-liquidity caused by the COVID-19 pandemic outbreak, the financial markets stress will impact on global economy. This severe crisis will fluctuate in global exchange market. 
Now, it is seen that if the manufacturing products are greatly damaged in many ways during the coronavirus crisis, the global economy will turn into a turbulent shape. The negative impact will fall on the global market economy.

\section{OECD}

According to the Organization for Economic Co-operation and Development (OECD), important measurements are very much essential to prevent coronavirus and save the health system of millions of people. In this regard, the governments as well as the conscious citizens of the vulnerable countries should take initiatives and co-ordinate with each other with a view to holding the balance of the economic wheel. Certainly, these steps taken by the experts will lead to significant short-term declines in the GDP for the major economies. The coronavirus pandemic outbreak is a major challenge for creating the global economic crisis.

OECD Secretary General Angel Gurria, in the G-20 virtual summit points out that the lockdown due to coronavirus will directly affect major sectors amounting to up to one-third of the gross domestic product in the global economies. For each month of containment, there will be a loss of $2 \%$ points in the annual GDP growth. Tourism sector will face an output decrease as high as $70 \%$. Major economies will fall into a recessive satiation. Gurria comments in the G-20 summit statement regarding the global economic crisis:

The high costs that the public health measures are imposing today are necessary to avoid much more tragic consequences and even the worse impacts on our economies tomorrow [...] Millions of deaths and collapsed health care systems will decimate us financially and as a society, so slowing this epidemic and saving human lives must be governments' first priority [...] Our analysis further underpins the need for sharper action to absorb the shock, and a more coordinated response by the governments to maintain a lifeline to the people and a private sector that will emerge in a very fragile state when the health crisis is past.

This quote implies that public health steps are very much important to prevent the coronavirus pandemic outbreak. Since millions of untimely deaths and collapsed health care systems decimate the global population, the global leaders should find out immediate measurements to save human lives. To invigorate the worse economy, the international agencies, including UNDP, WB, IMF, ILO and OECD must take initiatives.

In his statement, Gurria builds on a recent call for a "Global Marshall Plan" to counteract the pandemic's effects on the global population. To inoculate economies to the current and future shocks, he urges the G-20 leaders to act immediately so that they can recapitalize health and epidemiological systems. Leaders need to mobilize all macro-economic levers, including monetary, fiscal, and structural policies. Gurria further says that existing trade restrictions will damage the medical supplies. The governments should provide support to the vulnerable countries of the world. They ought to share and implement the best practices so that they can support the medical workers and all individuals, employed and unemployed people. The global leaders need to keep businesses afloat, particularly small and medium-sized firms, with their special support packages in hardest hit sectors, for example tourism industry and garment industry.

Gurria emphasizes on the fact that implications for the yearly growth domestic product growth will rely on the important factors, including the magnitude and duration of the national shutdowns, the extent of reduced demand for goods and services in other parts of the economy, and the speed at which significant fiscal and monetary support will be effective. In many economies, impacts come from the hit to output in retail and wholesale trade, and in professional and real estate services. There are notable cross-country differences in many sectors, with the closures of transport manufacturing relatively important, while the decline in the tourist and leisure activities is comparatively important. The impact of business closures will result in reductions of $15 \%$ in the level of output throughout the global economies and major emerging-market economies. In the median economy, output may decline by $25 \%$.

Variations in the effect across economies may reflect differences in the composition of output. Many countries where global tourism is important but affected severely by shutdowns and limitations on the global travel. At the other extreme, countries with the sizeable agricultural and mining sectors, oil production may experience smaller initial effects from the containment measures though output will be hit by the reduced global commodity demand. There will also be some variation in the timing of the initial impact on the output across economies through reflecting differences in the timing and degree of containment measures.

The OECD commits its expertise to support the governments in developing the effective policies in any sector necessary to slow the pandemic spread and blunt its economic and societal effects from health, taxes, labor, and employment to SMEs, education, science and technology, trade and investment and so on (OECD, 26 March 2020).

\section{Unemployment}

Unemployment problem is one of the major challenges for the millions of people around the world. If economic crisis begins to increase as an alarming rate, unemployment rate will become severe in the developing countries. Unemployment will be greatly 
responsible for creating the global economic crisis. According to the ILO 2020, the coronavirus pandemic outbreak will affect not only the low paid workers, but also the young people in all aspects of their lives. Women, who are employed in those sectors, are likely to be affected, for instance nurses and unprotected workers in the so-called gig economy and migrants. If the global economic crisis is severe in the coronavirus affected countries, certainly the unemployment rate will increase. As result, a vast majority of the global population will lose their job. Unemployment rate will be on the increase in the developing countries, including Asia, Africa and Middle East.

To get rid of unemployment, the governments must take immediate measurements and must ensure the safety of all citizens and increase the economic growth rate. It is the duty and responsibility of the head figures of any countries of the world to prevent the current coronavirus pandemic spread by all means. To remove unemployment is the only means is to create economic opportunity for all sorts of countrymen in any states. Moreover, the globally reputed organizations, like UN, WB, IMF, ILO, WEF, UNESCO, UNDP, etc. along with the developed countries of the world must function concertedly to ensure the economic safety and opportunities.

\section{Capital Flight}

According to the economists, capital flight is regarded as a large scale exodus of the financial assets and capital from a nation owning to the political or economic instability, currency devaluation or the imposition of the capital controls. Capital flight can be legal when the foreign investors repatriate capital back to their mother country, or it can be illegal, which may happen in economies with capital controls that will restrict the transfer of assets out of the country. Capital flight may impose as a big burden on the under developing countries, including Bangladesh since the lack of capital hurdles economic growth may lead to the lower living standards [11].

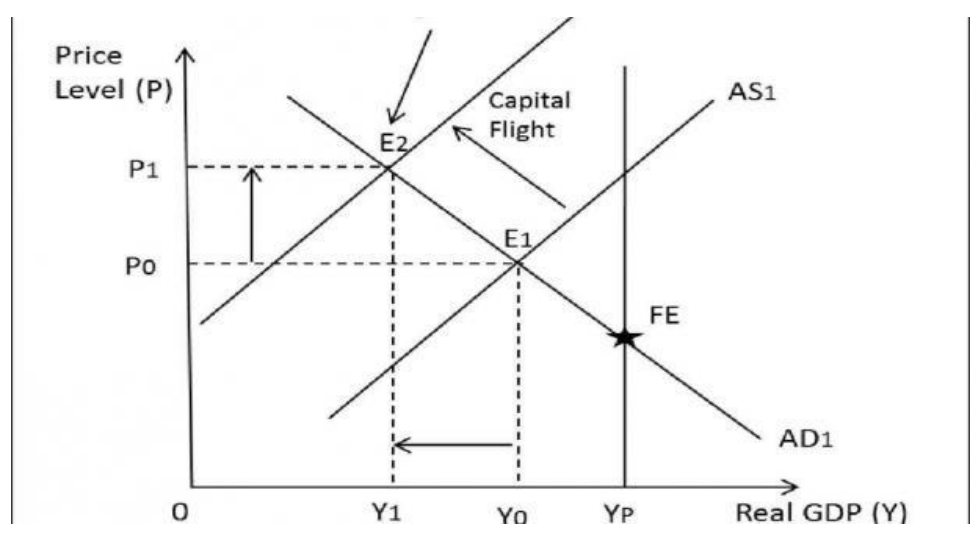

According to the Institute of International Finance, the pandemic will impact negatively on the capital flight and a sharp reversal of international investment in emerging international markets. Whereas 24-emerging markets, like China, India, South Africa and Brazil, have a net inflow of investments of US\$79bn in 2019, US\$70bn in investments exited such countries in the last two months (The New York Times, 2020).

The decision taken by the G-20 governments is to do whatever they like to lessen the socio-economic fallout owning to the coronavirus pandemic and to ensure cross-border flows of the vital medical supplies, agricultural products and other goods and services should be given priority (The Guardian, 2020). If there is no alternative means for capital, the economic condition will be paralyzed.

This capital flight reignites fears that countries, Argentina, Turkey or South Africa, will slid towards the insolvency and default in a very near future, which may be accelerated by the currency depreciations in such countries. Argentine peso continues to devalue and decreased by another 6\% against the dollar in 2020 . Similarly, Turkish lira drops by $10 \%$ since January and, as a result, the investors will pull money out and Turkish companies will be facing bankruptcy. Similarly, this situation will be becoming equally dire in the low-and middle-income countries of the world; it will also require an urgent attention from the policymakers and the international community. To stabilize capital flight, the global leaders must take initiatives. Since the prosperity and economic development largely relies upon the capital flight, the governments must find out a real solution during this difficult situation.

\section{Contraction of Foreign Direct Investment (EDI)}

Foreign direct investment is greatly responsible for the economic prosperity of a country. In this regard, the foreign investors need to be allowed to do business freely and fairly in a target country. Then it will be possible to bring prosperity in a country. The government must take important initiatives to stabilize FDI. 
However, a foreign direct investment is an investment in the form of a controlling ownership in a certain business within a country by an entity based in another country [12]. In this way, EDI will be differentiated from a foreign investment by a direct control. FDI may be made either inorganically by buying a company in the target country or organically by extending the operations of a prevalent business in that country.

Similarly the pandemic effect is dramatic when we look at the Foreign Direct Investment (FDI). On 26 March 2020, UNCTAD assumes a collapse of the global FDI by $30 \%$ to $40 \%$ during 2020-2021, more than the previous projections of $5 \%$ to $15 \%$ two weeks earlier.

The countries severely affected by COVID-19 will be hardest hit, other countries are also likely to feel the virus's full-impact as supply chain disruptions on the investment prospects. Over two-thirds of 100multinational companies tracked by UNCTAD issue statements on the effects, the virus has had on the global trade. Many companies begin to reduce the capital spending in the affected countries. According to the economists, the impacts of the fatal coronavirus on the global trade and business will be severe and dreadful. Consequently, the foreign direct investment will become looser to a large extent. If the foreign investment policy is paralyzed in the vulnerable countries and regions, a large number of companies and industries will have to face a dire results of economic crisis.

\section{Supply Shock}

According to the supply shock, production may get affected. Contrarily, due to the reductions in labor supply as a result of the infected workers through reducing many people who are involved in the work, because value chain may get disrupted. A supply shock is an event that may drastically increases or decreases the supply of a commodity or service, or of commodities and services in general. This drastic change may affect the equilibrium price of the goods, services or the general price level.

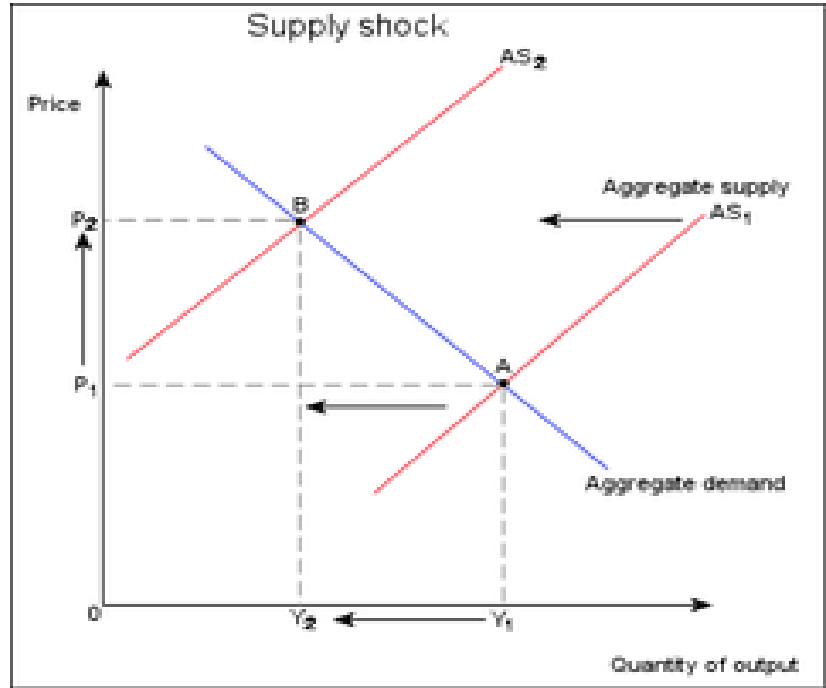

In the short run, an economy-wide negative supply shock may shift an aggregate supply curve leftward by lessening the output and increasing the price level [13]. Such as, the imposition of an embargo on trade in oil may occur an adverse supply shock, as oil is a main factor of production for a variety of goods. A supply shock may happen stagflation owning to a combination of rising prices and falling output. On the other hand, in the short run, an economy-wide positive supply shock may shift an aggregate supply curve rightward by increasing output and decreasing the price level (p.849). A positive supply shock may be an advance in the technology shock which will make production more efficient through increasing output.

From the above discussion, it can be mentioned here that the commodity of a supply shock will impact on the price level in the vulnerable regions due to the coronavirus pandemic outbreak. The countries that depend on equipment and components from regions affected by the novel coronavirus will likely experience disruptions in the production system.

\section{Demand Shock}

According to the economic point of view, a demand shock is a drastic event that may increase or decrease demand for any goods for the time being. A positive demand shock may increase an aggregate demand $(\mathrm{AD})$; on the other hand, a negative demand shock may decrease an aggregate demand. The prices of goods or services are likely to rise and fall due to the demand shock. While any demand for goods or services increases, its price increases due to the shift in the demand curve to the right side. On the contrary, while demand decreases, its price decreases owning to the shift in the demand curve to the left side. Demand 
shocks originates from the changes of any things, like government spending. For example, a taxpayer owes the government less money after a tax cut, freeing up more money for his personal spending. While a taxpayer uses his money for buying goods and services, prices go up.

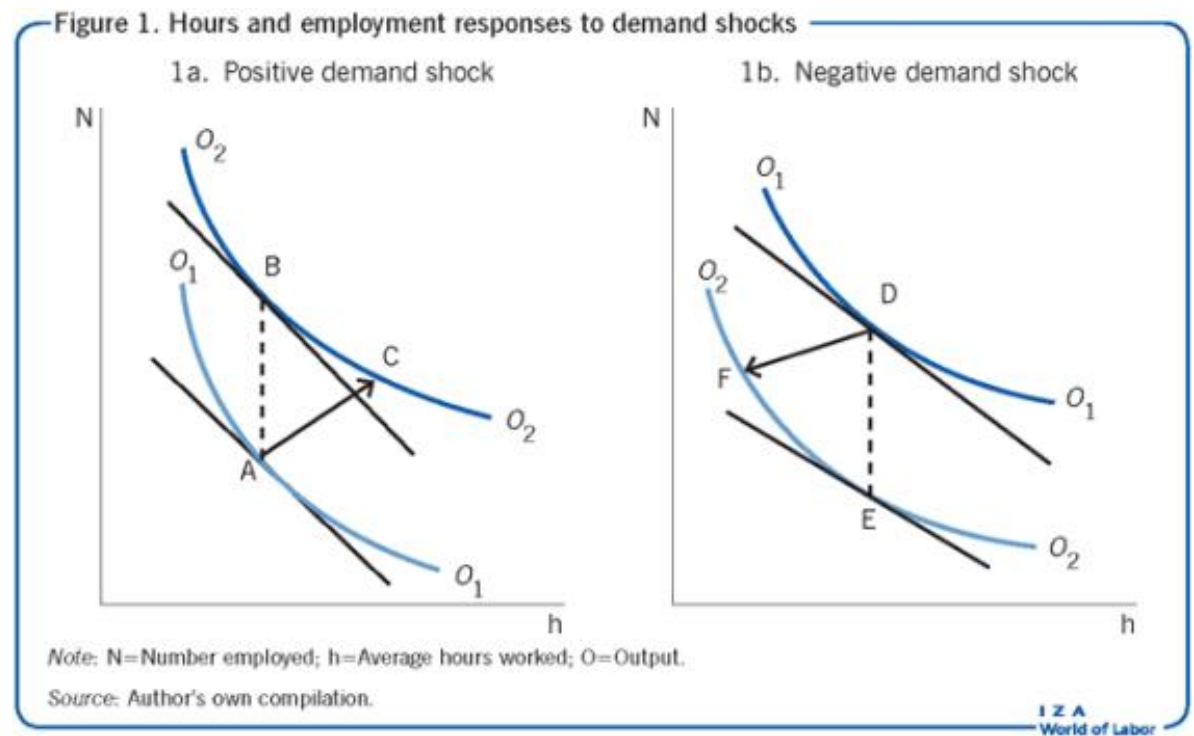

However, demand for manufactured goods may decrease as a result of the coronavirus pandemic outbreak. This may happen for the two reasons: Firstly, the propensity to consume decreases as the infected workers who will have to stay at home with a view to maintaining social distancing. For this purpose, measures emphasize savings on expenditures. Secondly, firms, which are experiencing disruptions in the production system will decrease their consumptions of the goods. Supply and demand shocks may manifest differently in the infected countries.

Economies in China, Europe, UK, USA Canada, Australia, France, Italy, Germany, India, and Bangladesh may be affected by the direct impacts on the global population's health condition. Most of the developing countries, including Bangladesh are mostly affected by the indirect impacts on their level of the inter-linkages with the countries affected by the coronavirus for which the demand for goods or the supply of goods or services will also get disrupted.

However, the COVID-19 pandemic outbreak will impact on the developing countries, like India, Bangladesh, Pakistan, Afghanistan, and Myanmar. The commodity of any prices will rise and fall due to the demand shock. Similarly, it will not be wrong to say that the developing countries, like USA, Spain, UK, Canada, France, China, Australia, Russia, and Germany will also be affected by a reduction in commodity prices, such as copper, oil driven by the decreased international demand for such goods. As a result, both the developing and the developed countries will experience drop in the production of the transformed manufactured goods and services.

\section{Manufacturing Industries}

Coronavirus has now rapidly broken out around the world. According to IBIS World, relevant impacts are being registered in Australia, Canada, Germany, New Zealand and the United States. Recurrent losses in these countries are reported in the domestic market, particularly in the food industry owning to the closure of pubs, restaurants, and other caterers. Moreover, heavy losses are being registered in the international markets in the automotive industry, for example a huge decrease in sales of $82 \%$ in Germany, and in the high-tech industries, like computers and electronics, the traditional champions of the comparative advantage in the developed countries of the globe.

Since coronavirus is spreading out randomly across the globe, a large number of population will be getting affected and infected. Its dire result will certainly impact on the global economy. At one time, many nations living in the developing countries of Global South, Middle East and Africa will have to face famine and die of coronavirus prematurely. Millions of people will be unemployed if this coronavirus crisis is on the increase. And, the global economy will be disrupted in all aspects. There will be no means to protect this newly born fatal coronavirus it goes beyond control.

According to Disease Control and Prevention, coronavirus has been regarded as an epidemic by the US Centers for Disease Control and Prevention and the WHO has raised the status to that of a pandemic an infectious disease that will be able to infect the people easily and spread from person to person in an efficient and sustainable way. 
According to economists, technology companies, apparel makers and industrial-equipment manufacturers, as well as shipping companies, hospitality chains, airlines and the luxury goods sector will be among those hardest hit by the new coronavirus. Economic slowdown may derail US plans to increase exports of farm produce, energy and manufactured goods to China by delaying any real recovery in the distressed farm and other areas of the US economy. The manufacturing companies and industries, which are supplying their goods and services around the world, will be greatly vulnerable. For instance, manufacturing companies and manufactured goods or services of China will be greatly damaged in this sense that people's demands will automatically be decreased due to the coronavirus pandemic outbreak in the Wuhan city.

\section{Electronic Products}

A big portion of electronics comes from Chinese factories in Bangladesh. Many technological companies have warned that they will not meet their quarterly estimates because of the factory closures. They anticipate delays in the production and shipment of existing models and introduction of the next generation models. Other electronics producers are forced to increase prices on products, like refrigerators, air conditioners, microwave ovens, washing machines, and televisions owning to the short supplies due to the coronavirus pandemic outbreak. In the global markets, the demands of the Chinese electronics will be decreasing because of the infection. Instead, the companies of other countries will try to invent electronics to capture the global markets.

The demand of the electronic goods of the vulnerable countries will begin to decrease if the coronavirus crisis will prolong. Prices will get disrupted when the customers are unwilling to purchase the electronic goods of the infected manufacturing companies. Thus the adverse situation will create in the global market economy.

\section{Hospitality, Tourism and Cruise Ships}

Hospitality, tourism, and cruise ships play an important role for the economic prosperity and development of a country. But, now-a-days, many countries curtail inbound tourism with a large number of coronavirus crisis. The European Union's industry chief estimates $€ 1$ billion losses per month in tourism sector due to the virus pandemic outbreak around the world. One of the largest losses stems from a decline in visitors from China, who represent a lucrative market for tourism and a large population of luxury goods purchasers. Cruise operators expect a hit than initially anticipated, as a result of trip cancellations in Asia. If suspension of operations in Asia lasts through the end of April, the losses will amount to $\$ 385$ million to $\$ 445$ million [14]. The pandemic outbreak has impacted severely on hospitality, tourism and cruise ships of
China. People's demand for Chinese tour will be greatly decreased. The tourist spots of the vulnerable countries will be largely damaged. Like before the tourists will not want to travel the affected regions.

\section{Oil Prices}

As lockdowns are forcing factories and multinational companies to close and stop people from travelling, the global demand for oil may reduce by 29 million barrels per day. It is very difficult to ascertain that the price of any commodity, including oil prices may dip into the negative territory. COVID19 pandemic outbreak has already promoted lockdowns, shuttered factories and stopped people from travelling. The global economy is contracting day by day. The pandemic has also reduced the global demand for oil by about 29 million barrels per day from about 100 million a year ago. OPEC and other producers have agreed to cut production by 9.7 million barrels a day, far less than the decrease in demand by leaving a huge surplus of oil on the global markets. Many oilimporting countries have stored large quantities of oil through taking the advantage of cheap prices. Some oil producers, hoping to maintain their market share, have taken to storing their excess oil in the sea, leasing tankers at high costs. Some are supposed to have paid in excess of US\$100,000 per day for each tanker.

The longer the COVID-19 pandemic lasts, the greater the damage oil producers will endure. It is hard to tell how oil prices will rise up once the pandemic subsides. They will likely go higher as marginal producers are eliminated, but not for the long time. Using oil and other fossil fuels is no longer consistent with avoiding the expected disasters of the climate change. Oil is increasingly becoming a stranded asset [15].

It needs no telling the fact that the oil prices will be increased due to the global lockdown because the oil producers companies did not supply. Generally, we know that oil of the Middle East countries is supplied throughout the world. But, due to the terrifyingly difficult situation, the oil producing companies are not supplying. The high-tech transport is now facing a critical situation.

\section{Pharmaceuticals and Healthcare}

The US Food and Drug Administration (FDA) requires growers and manufacturers under its jurisdiction to notify the agency of any expected supply disruptions. According to a statement issued by this agency, at least one drug is in short supply owning to the coronavirus outbreak. India's pharmaceutical industry expects supply issues relating to coronavirus. The Trade Promotion Council of India estimates that $85 \%$ of the active pharmaceutical ingredients imported by India are from China, and notes that two-thirds of imports of the bulk drugs and drug intermediates in 2018 and 2019 were from China. The demands of 
Chinese medicine or drugs and healthcare equipment will fail to hold the previous status in the global markets. As a result, the global pharmaceutical industry and healthcare system will automatically get collapsed or disrupted. Its impacts will fall in the vulnerable countries of the world.

\section{Fashionable and Luxurious Products}

Fashion and luxury goods plan a significant role for the economic development of a country. These sorts of goods are absolutely dependent on the people's capacity of income source, especially women are very much interested to purchase fashionable and luxury goods, including furniture, perfume, gold and diamond made-rings, bracelets, and chains in many countries of the world. According to David Roberts, a luxury product can be identified by comparing the demand for the goods at a different time and with a different income level. While income goes up, demand for luxury goods goes up even more than income went up. While income goes down, demand for any luxury goods go down even more than income went down [16]. For instance, if any income goes up $1 \%$, and the demand for a product goes up $2 \%$, then the product will be a luxury good. In economics, a luxurious good is such a product for which demand may increase more than proportionally when any income rises, in order that expenditures on the products will become a greater proportion of the overall spending. Luxurious goods, like perfume, vanity bags, watch, spectacles, diamond necklace, etc. are in contrast to necessary products, where demand may increase proportionally less than income source.

Fashion industry is particularly vulnerable. Foreign luxurious brands are a natural choice for the international tourists, who spend roughly $\$ 200$ billion a year on the luxurious goods in the US alone for instance. Luxurious goods makers' projects coronavirus will have a material negative effect on the luxury demand. Apparel makers also expect to see the revenues decline because of the outbreak [17]. Fashionable and luxurious goods which are produced in China or global south and then, they are sold out in the global markets, like Europe, USA, Austria or Russia. A portion of profit would come from exporting fashion and luxury goods markets. But, that reputation will get damaged due to the coronavirus infection. Asian luxury goods' companies will have to wait a lot of time to fulfill their economic loss. According to economists, if the demand of any goods or products will lose in the market or among the customers, the supply of those products will come down automatically to a large extend. They also expect that Chinese fashionable and luxurious goods will fall into this category.

\section{Recessive Impacts on Bangladesh National Economy}

Bangladesh mainly depends on the garments industry. Most of her income source comes from the garments sector. To invigorate our national economy, the government should take strict decision to contain the coronavirus crisis. Those who work in the garments industry, their health condition must be ensured. PPE needs to be provided for all sorts of garments workers without making any delay. At the terrifyingly difficult time, it is the foremost duty and responsibility of the government to ensure the safety of the vulnerable communities living in the different parts of the country.

According to Faysal Swavan (14 March 2020) [18], coronavirus is not only a health risk, but also shaking up the negative impacts on the entire world economy. As a result, Bangladesh's GDP growth may also decline. People in the country are losing their jobs. Many people of the world are getting isolated from each other due to the panic of dreadful coronavirus. All the major global events are getting closed starting from the stadium to the big one. Owning to the closure of schools, colleges, universities, and business institutions, economic activity has been declining. World airlines are losing their existence because restrictions on the movements have been imposed. A large number of business institutions are likely to be indebted. The main stock market is getting collapsed each and every day.

J. P. Morgan points out that the next two quarters will see a negative growth in the global economy because of the impacts of fatal coronavirus. OECD, an organization of the developed countries of the world, reports that the economic growth of the year 2020 will half-decline more than the year 2019. According to a Bloomberg report, coronavirus will cause \$ 2.7 trillion damage to the global economy, which will be equal to the GDP of the entire UK. Even the United States, Europe, and Japan are likely to fall into recession [6].

\section{Garments Industries}

In this terrifyingly difficult situation, export earnings in Bangladesh are on the decline. From July to February, the growth rate has slowed down to $4.7 \%$. Clothing exports have continued to decline. Europe and the United States are the main markets for this product. Coronavirus has already begun to affect the global market very negatively. Bangladesh exported \$ 143 million worth of clothing last year. Gradually the same situation is being made all over Europe, even in the United States. About $62 \%$ of Bangladesh's garment exports come from Europe and 18\% from the United States. Entrepreneurs in the readymade garment industry comment that they have already begun to shrink demand. Rubana Haque, President of BGMEA, a factory owners' organization, tells Deutsche Welle that sales in the US retail market have already declined by three-tenths of a percent; and the buyers' demands have begun to decline. 


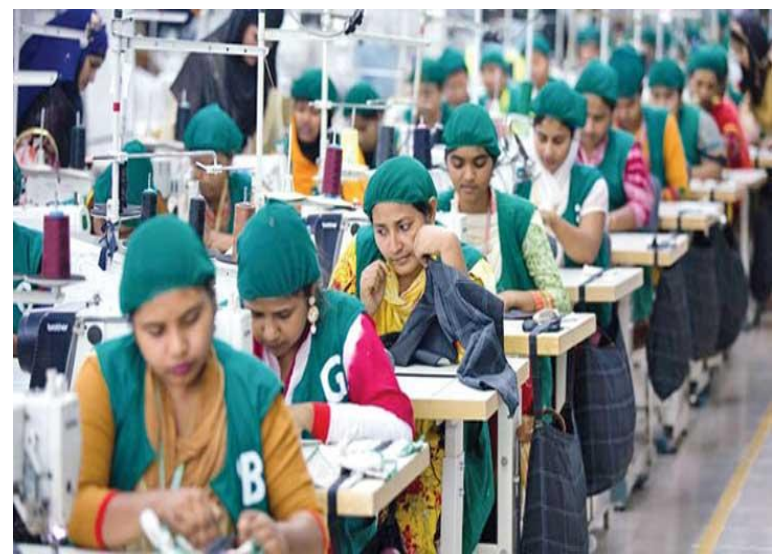

Siddiqur Rahman, the Vice President of FBCCI, says: "We are afraid of Europe. If coronavirus crisis is widely spread there; the demand for clothing will be greatly reduced. How can people buy clothes if they can't get out of their house?" What he wants to mean here is that the price of the cloths may slow down in this critical time.

\section{Remittance}

In recent times, most of the indicators of Bangladesh's economy are losing its opportunity; among which remittance was doing better. The first eight months of the current fiscal year, the expatriates sent $\$ 1042$ million to the country, which is $10 \%$ more than the year 2019. Now it will be difficult for Bangladesh to keep this momentum. In countries where people are infected by coronavirus, economic activity has already declined. The Bangladeshi workers or businessmen living in abroad cannot send money to their families. If they are unable to earn finance, naturally, remittance will be on the decrease. This will have a great impact on the reserve of foreign currency. Due to the coronavirus pandemic outbreak, the biggest drop is found in fuel oil prices in the world market after 2008 years. Crude Brent is being sold out only \$33 this year in lessening $50 \%$. There is no possibility that this situation will end so easily, because the global economy is slowing down; the demand for energy and fuel will decrease. On the other hand, Saudi Arabia and Russia did not agree to reduce the production of oil in order that they could accommodate the global market. If this situation continues, major losses will be attributed to the countries in the Middle East's energy-dependent economies. The bulk of Bangladesh's expatriate income source comes from these regions.

\section{Impacts on Internal Economy}

The two major driving force of Bangladesh's economy are manpower export and remittance. If export earnings are reduced, there will be a downfall in the income of the workers, or an uncertainty of employment in the industrial factories of the country will be brought about. On the other hand, if the expatriate reduces sending money in the country, their families will not be able to spend as much as before. This will have a negative impact on business and at the same time, the demands of business will be on the decrease. Consumer product makers will suffer from losses if demand falls. Again, if the outbreak of coronavirus is severely found in Bangladesh, the velocity of national economy will slow down. Above all, it will be a major challenge for the government to meet the current GDP growth target. Asian Development Bank (ADB) has already said that Bangladesh's GDP is likely to decline by a tenth of a percent in the worst case scenario. It will cost them a total of 3 billion dollars. 8 lakh 94 thousands and 930 people will lose their jobs. Such information was provided in an affidavit by the English daily The Daily Star.

\section{Prospects in Economy}

Of course, there are some places to expect that Bangladesh may buy fuel from the world market entirely. Now, the cost of import will be much lower than before; the price will be reduced. If the government cope with prices in the market accordingly, the production and transportation costs of the industry will decrease slowly.

If the government does not reduce the price of fuel, the importer company Bangladesh Petroleum Corporation (BPC) will enjoy the full-benefit. Many international organizations have banned or reduced the import of goods from China due to the coronavirus pandemic outbreak. As a result, Bangladesh is likely to benefit from the garment sector [19]. The survey was conducted on 200 international buyer companies. Companies say that they are now leveraging products from other countries rather than China. Of those, Vietnam, India and Bangladesh are included. But, if the coronavirus crisis prolongs for several months or more, the global economy will have to face a dire result [20].

Now it is clear to us that Bangladesh is one of the most vulnerable countries of the world. Many people are getting affected and infected by the coronavirus. Death toll and confirmed cases are on the increase very rapidly. How much loss Bangladesh economy will face is difficult to ascertain. 


\section{CONCLUSION}

According to International Monetary Fund, due to the great lockdown, the worst economic situation has turned down since the great depression. The whole globe has changed dramatically since January 2020. A rare disaster, like coronavirus pandemic outbreak, has resulted in a mercilessly large number of vulnerable communities being paralyzed. The Head of the International Monetary Fund (IMF) has warned that the coronavirus pandemic spread has turned the global economic growth very sharply negative in the year 2020. As countries implement necessary quarantines and social distancing maintenance to prevent the difficult crisis, the world has been put in a great lockdown. The magnitude and speed of collapse in economic activity that has followed is unlike anything experienced in the $21^{\text {st }}$-century age. It is unbelievable and unthinkable. Similarly, the case is that once the sailors and the shipping companied would think that the Titanic Ship was unsinkable. It is uncertain when anything would happen. The coronavirus pandemic is unexpected to us.

The reasons said above, in this paper, the current researcher has tried to highlight the negative impacts of the novel coronavirus (COVID-19) pandemic outbreak on the global economy. He has taken all sorts of information and reports of macro economies made by the powerful international organizations, like UNCTAD, OECD, UN, DESA, IBIS, and CDCP. This study has exposed the terrifyingly difficult situation of the vulnerable communities due to the infection and affection of the fatal virus. Even their normal living condition has become paralyzed owning to the poor economy. The global economy has become stagnant and unstabilized. For this purpose, the researcher has wanted to highlight the duty and responsibility of the powerful leaders with a view to invigorating and stabilizing the global economy. The impacts of the coronavirus on unemployment, capital flight, contraction of foreign direct investment, supply shock, demand shock, manufacturing industries, electronic goods, hospitality, tourism and cruise ships, oil prices, pharmaceuticals and healthcare, fashionable and luxurious products globally have been discussed very clearly. The negative effects of the COVID-19 on Bangladesh national economies, including garment industries, remittance, and internal economy have been emphasized.

\section{REFERENCES}

1. Gopinath G. "The Great Lockdown: Worst Economic Downturn since the Great Depression." International Monetary Fund. (2020 April 14).

2. "The Great Lockdown: Worst Economic Downturn since the Great Depression." International Monetary Fund Blog.

3. Islam F. "Coronavirus recession not yet a depression.” BBC News. 2020 March 20.

4. Elliott L. "'Great Lockdown' to rival Great Depression with $3 \%$ hit to global economy, says IMF." The Guardian. 2020 March 14.

5. "The Great Lockdown: Worst Economic Downturn since the Great Depression. ” International Monetary Fund Blog.

6. Johnsen M, Juliana K, Lauren FM. "A third of the global population is on coronavirus lockdown here's our constantly updated list of countries and restrictions." Business Insider Australia. 2020 March 14

7. "World Economic Outlook, April 2020: The Great Lockdown. " International Monetary Fund.

8. https://economictimes.indiatimes.com/news/intern ational/business/global-economy-could-shrink-byalmost-1-in-2020-due-to-covid-19-pandemicunited-nations/articleshow/74943235.cms

9. https://www.weforum.org/agenda/2020/03/corona virus-covid-19-cost-economy-2020-un-tradeeonomics-pandemic

10. https://www.unido.org/stories/coronaviruseconomic-impact

11. https://www.investopedia.com/terms/c/capitalfligh t.asp

12. Foreign Direct Investment Definition from Financial Times Lexicon.

13. Hall R, Marc L. "Economics: Principles and Applications." Cengage Learning, 2012; 849.

14. Sampson (18 February 2020).

15. Kubursi A. "Oil crash explained: How are negative oil prices even possible?" The World Economic Forum. 2020 April 21.

16. Roberts D. "Why rich people use so much more energy." 2020 March 20.

17. The Centers for Disease Control and Prevention (11 March 2020).

18. Swavan F. "What are Impacts of Coronavirus on Bangladesh Economy?" 2020 March 14.

19. Hong Kong-based company has published this report.

20. https://www.dw.com/bn/what are the harmful impacts of coronavirus on Bangladesh economy? 